\title{
The Effect of Preservative Methods on the Yield, Water Content and Microbial Stability of Dairy Products
}

\section{*EBABНAMIEGBEBHO, P A; IGENE, J O; EVIVIE, S E}

\author{
Food Science and Technology Division, Department of Animal Science, Faculty of Agriculture, University of Benin, PMB 1154, Benin City, \\ Nigeria \\ *Correspondence Author: peterakhere@yahoo.co.uk
}

\begin{abstract}
This study investigated the effects of various methods of processing on the yield and microbial stability of smoke-dried beef. Five different production treatments were considered for evaluation in this study- raw smoke-dried meat (RSD), raw salted smoke-dried meat (RSSD), salted cooked smoke-dried meat (SCSD), cooked smoke-dried meat (CSD) and cured smoke-dried meat (CUSD) respectively. The water content (water activity) of the treatments in relation to storage life of the dairy products was determined. All samples were smoke-dried for five hours and each was equilibrated to water activities of $0.11,0.33$ and 0.75 for two weeks undisturbed. A control experiment was also prepared. Analysis of variance was carried out on all data generated and the difference among the means were compared using Duncan Multiple Range Test. Results showed that cured smoke-dried beef was the most acceptable organoleptically and most shelf stable because there was insignificant microbial activity after twelve weeks of storage ( $p>0.05$ ). It also had the highest yield of $56.35 \%$ while raw, smoke-dried beef had the lowest yield of $32.1 \%$. Significant microbial activities were recorded in other samples at twelve weeks of storage due to treatment effects $(\mathrm{p}<0.05)$. The organisms isolated in smoke-dried beef were Aspergillus flavipes, A.flavus, A.niger, A.aureous and Fusarium spp. A. flavipes was isolated from samples of water activity at 0.33 while A.niger was isolated from samples of water activity at 0.11 . It was recommended that the reduction in moisture content of smoke-dried beef into water activities of 0.11 and 0.33 be vigorously pursued to ensure a safe and shelf-stable product for effective quality retention and distribution. This work will help local communities realize the importance of how the combined effects of using preservatives and how moisture content significantly $(\mathrm{p}<0.05)$ extended the shelf life of smoked and stored dairy products. @ JASEM
\end{abstract}

Key Words: Meat, Microrganisms, Smoking, Water activity

The development of enhanced taste, increased shelf life and the improvement of product appearance are the main reasons for smoking meat. The preservative effect of smoking process is partly due to drying and partly due to deposition of natural chemicals from wood smoke unto the food which inhibits the growth of bacteria and other harmful micro organisms (Garbutt, 1997). These chemicals vary in their bacteriostatic and bacteriocidal effects. Meat can be smoked in a variety of ways but as a principle, the longer it is smoked, the longer its shelf life may be. Hot smoking is often the preferred method because the process requires less control than cold smoking and the shelf life is longer (Eboigbe, 1999; Jacob, 1989; Pearson and Tauber, 1984). The smoking process in tropical Africa is by high temperature which involves smoking, drying and high temperature treatment (Igene and Tukura, 1986). Hot smoking employs hardwood subjected to complete combustion. The hot and light smoke emanating from the combustion cooks and dries the meat thereby resulting in shrinkage but produces a cooked, smokedried, shelf-stable product (Igene and Tukura, 1986). Meat may be smoked raw or cooked with or without salting (Igene and Tukura, 1986; Obanu, 1988; Pearson and Tauber, 1984).

\section{*Correspondence: peterakhere@yahoo.co.uk}

The microbial stability and safety of traditional smoked meat depends on the control of water activity and moisture content below the lower limit at which microorganisms are able to multiply and produce toxins (Jideani et al, 2000; Obanu, 1988; Okonkwo et al, 1994). Of the usual food-borne pathogens, only Staphylococcus aureus is able to grow in water activity as low as 0.86 and it has the ability to produce one or more potent toxins and grows rapidly over a wide range of $\mathrm{pH}$. It can easily gain access to meat through human handling hence there is need for sanitary handling during processing and post processing handling (Daniels, 1998; Newsome, 1994).

The water content of food may bear little relationship to its water activity. Water activity is a central factor that affects food composition, stability, safety and nutritive appeal. It also evaluates in qualitative terms how much of the moisture present in food is actually available for chemical reactions, microbial growth and activity (Ukhun, 1991; Ukhun and Dibie, 1989). Organisms will not only cease to grow below their minimum water activities but death may also occur at a rate determined by the method used to lower the water activity and how far the water activity is below the minimum (Asagbra et al, 1998; Ukhun, 1991). 
The Effect of Preservative Methods.....

Preservation methods that involve lowering the water activity of foods are addition of salt, addition of sugars or sugar alcohols, drying, freeze drying and freezing (Garbutt, 1997). The objective of this study therefore is to determine the best level of water activity for preservation of smoked beef stored for 12 hours.

\section{MATERIALS AND METHODS}

Preparation of the Experimental Laboratory: The preparation of the meat samples to produce smokedried beef was done at the Postgraduate laboratory of the Faculty of Agriculture, University of Benin. The experimental are was thoroughly washed, cleaned and disinfected.
Preparation of Smoke-dried Beef Samples: A cut of $5 \mathrm{~kg}$ beef (Longismus dorsi) was obtained from the beef carcass (trimmed of fat and connective tissues) was used for the experiment. It was further divided into five parts of $1 \mathrm{~kg}$ each to represent each of the treatments to be applied and a control. The $1 \mathrm{~kg}$ beef was fuer divided into five replicates of $200 \mathrm{~g}$ for each treatment. A sample of $10 \mathrm{~g}$ of fresh beef was kept refrigerated for microbiological analysis. Another sample of $10 \mathrm{~g}$ was also cut from those that had been handled to be refrigerated for microbiological analysis to determine the effect of handling on the microbial population.

Table 1: Experimental Treatment of Samples

\begin{tabular}{|l|l|l|}
\hline Composition & Abbreviation & Preparation \\
\hline Raw, smoke-dried & RSD & Smoked raw beef without additives \\
\hline Raw, Salted, Smoke-dried & RSSD & Smoked raw beef after brining in 10\% salt solution \\
\hline Salted, Cooked, Smoke-dried & SCSD & Boiled with 10\% salt solution before smoke-drying \\
\hline Cooked, Smoke-dried & CSD & Boiled without additives before smoke-drying \\
\hline Cured, Smoke-dried & CUSD & Cured for 48hrs before smoke-drying \\
\hline
\end{tabular}

Equilibration of Water Activity $\left(a_{w}\right)$ : Samples from each of the five treatments were equilibrated to water activities of $0.11,0.33$ and 0.75 following the procedure of Rockland and Nishi (1980). The $0.75 \mathrm{a}_{\mathrm{w}}$ was prepared by making a saturated solution of sodium chloride $(\mathrm{NaCl})$ using a desiccator. A portion of each of the samples was taken, labeled and placed in a desiccators separated by a wire gauze and sealed with Vaseline wax for two weeks undisturbed. The $0.33 \mathrm{a}_{\mathrm{w}}$ was prepared by making a saturated solution of magnesium chloride $(\mathrm{MgCl})$ in another desiccator. $20 \mathrm{~g}$ of each of the five treatments was taken, labeled and placed in a desiccator with wire gauze to separate them from the solution. This desiccator was also sealed with Vaseline and left for two weeks undisturbed. The $0.11 \mathrm{a}_{\mathrm{w}}$ was achieved by making a saturated solution of lithium chloride $(\mathrm{LiCl})$ in a desiccator and a portion was prepared following the procedure above.

Microbial Analysis: The microbial quality determination was carried out on the fresh beef and smoke-dried beef treatment samples including those equilibrated to water activities of $0.11,0.33$ and 0.75 . The total plate count (TPC) and fungi count were carried out following the procedure of Garbutt (1997). In each case, $1 \mathrm{~g}$ of treatment sample was ground in a sterile mortar and dissolved in $9 \mathrm{ml}$ of sterile water in a test tube allowed to stand for one hour. $1 \mathrm{ml}$ of the sterile stock was transferred with a sterile pipette into another $9 \mathrm{ml}$ test tube with sterile water until the fifth test tube. About $1 \mathrm{ml}$ of the fifth test tube was poured into a petri dish (replicated four times) which contain sterile molten potato dextrose agar (PDA). The petri dishes were inoculated at room temperature $\left(25-30^{\circ} \mathrm{C}\right)$ in a laboratory for 72 hours. The colony forming units $(\mathrm{cfu} / \mathrm{g})$ were counted and recorded accordingly. Any growth in the petri dish was identified and recorded.

Equilibration of Water Activity $\left(a_{w}\right)$ : Samples from each of the five treatments were equilibrated to water activities of $0.11,0.33$ and 0.75 following the procedure of Rockland and Nishi (1980). The $0.75 \mathrm{a}_{\mathrm{w}}$ was prepared by making a saturated solution of sodium chloride $(\mathrm{NaCl})$ using a desiccator. A portion of each of the samples was taken, labeled and placed in a desiccators separated by a wire gauze and sealed with Vaseline wax for two weeks undisturbed. The $0.33 \mathrm{a}_{\mathrm{w}}$ was prepared by making a saturated solution of magnesium chloride $(\mathrm{MgCl})$ in another desiccator. $20 \mathrm{~g}$ of each of the five treatments was taken, labeled and placed in a desiccator with wire gauze to separate them from the solution. This desiccator was also sealed with Vaseline and left for two weeks undisturbed. The $0.11 \mathrm{a}_{\mathrm{w}}$ was achieved by making a saturated solution of lithium chloride $(\mathrm{LiCl})$ in a desiccator and a portion was prepared following the procedure above. 
The Effect of Preservative Methods.....

Table2. Physicochemical characteristics of meat.

\begin{tabular}{|c|c|c|c|c|c|}
\hline Treatment & $\begin{array}{l}\text { Weight of } \\
\text { Pieces }(\mathrm{g}) \\
\end{array}$ & $\begin{array}{c}\text { Length of } \\
\text { Pieces }(\mathrm{cm})\end{array}$ & $\begin{array}{c}\text { Width of } \\
\text { Pieces }(\mathrm{cm})\end{array}$ & $\begin{array}{l}\text { Thickness of } \\
\text { Pieces }(\mathrm{cm})\end{array}$ & $\begin{array}{c}\text { Yield } \\
(\%)\end{array}$ \\
\hline \multicolumn{6}{|c|}{ Raw, Smoke-dried (RSD) } \\
\hline Before smoking & 210.00 & 5.00 & 5.00 & 5.00 & \multirow[b]{2}{*}{26.67} \\
\hline After smoking & 53.35 & 3.02 & 2.80 & 2.91 & \\
\hline \multicolumn{6}{|c|}{ Raw, salted, smoke-dried (RSSD) } \\
\hline Before salting & 200.00 & 4.97 & 5.01 & 4.89 & \multirow{3}{*}{29.27} \\
\hline After salting & 210.77 & 5.00 & 4.99 & 4.26 & \\
\hline After smoking & 58.54 & 3.06 & 3.16 & 3.21 & \\
\hline \multicolumn{6}{|c|}{ Salted, cooked, smoke-dried (SCSD) } \\
\hline Before salting & 200.00 & 5.00 & 4.91 & 5.10 & \multirow{4}{*}{36.00} \\
\hline After salting & 210.76 & ND & ND & ND & \\
\hline After cooking & 139.74 & 4.40 & 4.30 & 4.30 & \\
\hline After smoking & 72.82 & 4.10 & 3.20 & 3.10 & \\
\hline \multicolumn{6}{|c|}{ Cooked, smoke-dried (CSD) } \\
\hline Before cooking & 200.00 & 5.00 & 5.00 & 5.00 & \multirow{3}{*}{32.10} \\
\hline After cooking & 108.20 & 3.12 & 3.22 & 3.40 & \\
\hline After smoking & 64.19 & 2.10 & 2.82 & 2.62 & \\
\hline \multicolumn{6}{|c|}{ Cured, Smoke-dried (CUSD) } \\
\hline Before curing & 200.00 & 5.00 & 5.00 & 5.00 & \multirow{3}{*}{56.35} \\
\hline After curing & 249.54 & 5.21 & 5.30 & 4.96 & \\
\hline After smoking & 113.80 & 4.10 & 4.02 & 3.86 & \\
\hline
\end{tabular}

ND—not determined

Microbial Analysis: The microbial quality determination was carried out on the fresh beef and smoke-dried beef treatment samples including those equilibrated to water activities of $0.11,0.33$ and 0.75 . The total plate count (TPC) and fungi count were carried out following the procedure of Garbutt (1997). In each case, $1 \mathrm{~g}$ of treatment sample was ground in a sterile mortar and dissolved in $9 \mathrm{ml}$ of sterile water in a test tube allowed to stand for one hour. $1 \mathrm{ml}$ of the sterile stock was transferred with a sterile pipette into another $9 \mathrm{ml}$ test tube with sterile water until the fifth test tube. About $1 \mathrm{ml}$ of the fifth test tube was poured into a petri dish (replicated four times) which contain sterile molten potato dextrose agar (PDA). The petri dishes were inoculated at room temperature $\left(25-30^{\circ} \mathrm{C}\right)$ in a laboratory for 72 hours. The colony forming units $(\mathrm{cfu} / \mathrm{g}$ ) were counted and recorded accordingly. Any growth in the petri dish was identified and recorded.

Statistical Analysis: The data generated in all cases were analyzed using the SPSS package and the completely randomized design. The Duncan Multiple Range Test was also used to test the differences between mean values obtained.

\section{RESULTS AND DISCUSSION}

Table 2 shows the physical characteristics such as length, width, weight and thickness of meat pieces used for the experiment. It also shows the yields from various treatment samples. From the table, the cured smoke dried beef (CUSD) had the highest yield of $56.35 \%$ followed by SCSD, CSD and RSSD. RSD has the least yield of $26.67 \%$ (SCSD- Salted Cooked Smoke-Dried, CSD- Cooked Smoke-Dried, RSSDRaw Salt Smoke-Dried).

Table 3 shows the relationship which the time of storage has on the microbial population. There was a decrease in the microbial population as the time of storage increased. The cured smoke-dried treatment (CUSD) had no microbial growth in the first three weeks until the fourth week. $\mathrm{N}$ microbial growth was also observed from $10^{\text {th }}$ to $12^{\text {th }}$ week of storage. Microbial growth occurred in other treatments throughout the period of storage. The low microbial growth in the cured smoke-dried sample may be due to the effect of nitrite as reported by Obanu (1988). 
The Effect of Preservative Methods.....

Table 3: Effect of Time of Storage on The Mean Microbial Population (cfu/g) of Smoke-dried Beef Stored for Twelve Weeks

\begin{tabular}{|c|l|l|l|l|l|}
\hline \multirow{2}{*}{\begin{tabular}{c} 
Time of $\begin{array}{l}\text { Storage } \\
\text { (Weeks) }\end{array}$ \\
\cline { 2 - 6 }
\end{tabular}} & RSD & RSSD & SCSD & CSD & CUSD \\
\hline 0 & $5 \pm 0.10^{\mathrm{a}}$ & $4 \pm 0.20^{\mathrm{a}}$ & Nil & $3 \pm 0.30$ & \\
\hline 2 & $5 \pm 0.20^{\mathrm{a}}$ & $6 \pm 0.21^{\mathrm{a}}$ & $1 \pm 0.10^{\mathrm{a}}$ & $4 \pm 0.12$ & Nil \\
\hline 4 & $3 \pm 0.03^{\mathrm{b}}$ & $6 \pm 0.12^{\mathrm{a}}$ & $2 \pm 0.01^{\mathrm{a}}$ & $5 \pm 0.11$ & $1 \pm 0.01^{\mathrm{a}}$ \\
\hline 6 & $5 \pm 0.10^{\mathrm{a}}$ & $3 \pm 0.02^{\mathrm{b}}$ & $2 \pm 0.01^{\mathrm{a}}$ & $4 \pm 0.21$ & $1 \pm 0.20^{\mathrm{a}}$ \\
\hline 8 & $3 \pm 0.13^{\mathrm{b}}$ & $3 \pm 0.13^{\mathrm{b}}$ & $3 \pm 0.02^{\mathrm{b}}$ & $2 \pm 0.12$ & $1 \pm 0.01^{\mathrm{a}}$ \\
\hline 10 & $3 \pm 0.20^{\mathrm{b}}$ & $2 \pm 0.04^{\mathrm{c}}$ & $2 \pm 0.01^{\mathrm{a}}$ & $2 \pm 0.33$ & Nil \\
\hline 12 & $3 \pm 0.01^{\mathrm{b}}$ & $2 \pm 0.30^{\mathrm{c}}$ & $1 \pm 0.01^{\mathrm{a}}$ & $2 \pm 0.22$ & Nil \\
\hline Mean & $4 \pm 0.02$ & $3.7 \pm 0.01$ & $1.57 \pm 0.02$ & $3.14 \pm 0.03$ & $0.4 \pm 0.03$ \\
\hline
\end{tabular}

Mean values on the same column with the same superscript are not significantly different $(p>0.05)$

Table 4: Effect of 0.11 Water Activity on the Microbial Quality of Smoke-dried Beef Stored for Twelve Weeks (cfu/g)

\begin{tabular}{|c|l|l|l|l|l|}
\hline & \multicolumn{5}{|c|}{ Treatment } \\
\hline $\begin{array}{c}\text { Time of } \\
\text { Storage } \\
\text { Weeks })\end{array}$ & RSD & RSSD & SCSD & CSD & CUSD \\
\hline 0 & Nil & Nil & Nil & Nil & Nil \\
\hline 2 & Nil & Nil & Nil & Nil & Nil \\
\hline 4 & $1 \pm 0.02^{\text {a }}$ & $1 \pm 0.20^{\text {a }}$ & Nil & Nil & Nil \\
\hline 6 & $1 \pm 0.01^{\text {a }}$ & $1 \pm 0.12^{\text {a }}$ & Nil & Nil & Nil \\
\hline 8 & $1 \pm 0.02^{\text {a }}$ & $1.4 \pm 0.11^{\text {a }}$ & Nil & $1.3 \pm 0.01$ & Nil \\
\hline 10 & Nil & Nil & Nil & Nil & Nil \\
\hline 12 & Nil & Nil & Nil & Nil & Nil \\
\hline
\end{tabular}

Mean values on the same column with the same superscript are not significantly different $(\mathrm{p}>0.05)$

Table 5: Effect of 0.33 Water Activity on the Microbial Quality of Smoke-dried Beef Stored for Twelve Weeks (cfu/g)

\begin{tabular}{|c|l|l|l|l|l|}
\hline Time of Storage (Weeks) & \multicolumn{5}{|c|}{ Treatment } \\
\cline { 2 - 6 } & RSD & RSSD & SCSD & CSD & CUSD \\
\hline 0 & Nil & Nil & Nil & Nil & Nil \\
\hline 2 & $2 \pm 0.01^{\mathrm{a}}$ & Nil & $1.1 \pm 0.02^{\mathrm{a}}$ & $2 \pm 0.02^{\mathrm{a}}$ & Nil \\
\hline 4 & Nil & $2 \pm 0.01^{\mathrm{a}}$ & $2 \pm 0.01^{\mathrm{a}}$ & $1 \pm 0.02^{\mathrm{a}}$ & Nil \\
\hline 6 & $3 \pm 0.11^{\mathrm{b}}$ & $2 \pm 0.02^{\mathrm{a}}$ & $1 \pm 0.02^{\mathrm{a}}$ & $2 \pm 0.01^{\mathrm{a}}$ & Nil \\
\hline 8 & $2 \pm 0.02^{\mathrm{a}}$ & $1 \pm 0.01^{\mathrm{a}}$ & $1 \pm 0.01^{\mathrm{a}}$ & $1.1 \pm 0.01^{\mathrm{a}}$ & Nil \\
\hline 10 & $1.1 \pm 0.03^{\mathrm{a}}$ & $1 \pm 0.02^{\mathrm{a}}$ & Nil & $1 \pm 0.01^{\mathrm{a}}$ & Nil \\
\hline 12 & $1 \pm 0.12^{\mathrm{a}}$ & & Nil & Nil & Nil \\
\hline
\end{tabular}

Mean values on the same column with the same superscript are not significantly different $(p>0.05)$

Table 4 shows the effect of water activity (low moisture content) and preservation methods on the shelf stability of the treatment samples. The most shelf-stable treatment (that is, no microbial growth was recorded) was the salted cooked smoke dried (SCSD) and the cured smoke-dried (CUSD). Microbial growth was recorded in the cooked smokedried (CSD), raw smoke-dried (RSD) and raw salted smoke-dried (RSSD). Table 5 shows the effect of 0.33 water activity (low moisture) content combined with processing/preservative methods on shelf stability of the treatment samples. There was no microbial growth in the cured smoke-dried (CUSD) sample. This may be due to the preservatives applied and the low water activity. There was also no significant difference between the treatment samples (p>0.05). Table 6 shows the effect of 0.75 water activity on the microbial population of the five treatments. No significant difference was observed in the cured smoke-dried sample as was in the other treatments except with little variation with respect to time in storage 
The Effect of Preservative Methods.....

Table 6: Effect of 0.75 Water Activity on the Microbial Quality of Smoke-dried Beef Stored for Twelve Weeks (cfu/g)

\begin{tabular}{|c|l|l|l|l|l|}
\hline Time of Storage (Weeks) & \multicolumn{5}{|c|}{ Treatment } \\
\cline { 2 - 6 } & RSD & RSSD & SCSD & CSD & CUSD \\
\hline 0 & Nil & $0.5 \pm 0.01^{\mathrm{a}}$ & Nil & Nil & Nil \\
\hline 2 & $1 \pm 0.10^{\mathrm{a}}$ & $1 \pm 0.02^{\mathrm{a}}$ & $1 \pm 0.10^{\mathrm{a}}$ & $2 \pm 0.10^{\mathrm{a}}$ & $1 \pm 0.11^{\mathrm{a}}$ \\
\hline 4 & $1 \pm 0.11^{\mathrm{a}}$ & $-2 \pm 0.02^{\mathrm{a}}$ & $4 \pm 0.02^{\mathrm{b}}$ & $1 \pm 0.11^{\mathrm{a}}$ & Nil \\
\hline 6 & $2 \pm 0.12^{\mathrm{a}}$ & $2 \pm 0.01^{\mathrm{a}}$ & $1 \pm 0.03^{\mathrm{a}}$ & $2 \pm 0.12^{\mathrm{a}}$ & Nil \\
\hline 8 & $1 \pm 0.10^{\mathrm{a}}$ & $2 \pm 0.11^{\mathrm{a}}$ & $2.1 \pm 0.11^{\mathrm{a}}$ & $3 \pm 0.13^{\mathrm{b}}$ & $1 \pm 0.11^{\mathrm{a}}$ \\
\hline 10 & $1.1 \pm 0.11^{\mathrm{a}}$ & $1 \pm 0.10^{\mathrm{a}}$ & $1 \pm 0.12^{\mathrm{a}}$ & $2 \pm 0.11$ & Nil \\
\hline 12 & $1 \pm 0.10^{\mathrm{a}}$ & $1 \pm 0.10^{\mathrm{a}}$ & Nil & $1 \pm 0.12^{\mathrm{a}}$ & Nil \\
\hline
\end{tabular}

Mean values on the same column with the same superscript are not significantly different $(\mathrm{p}>0.05)$

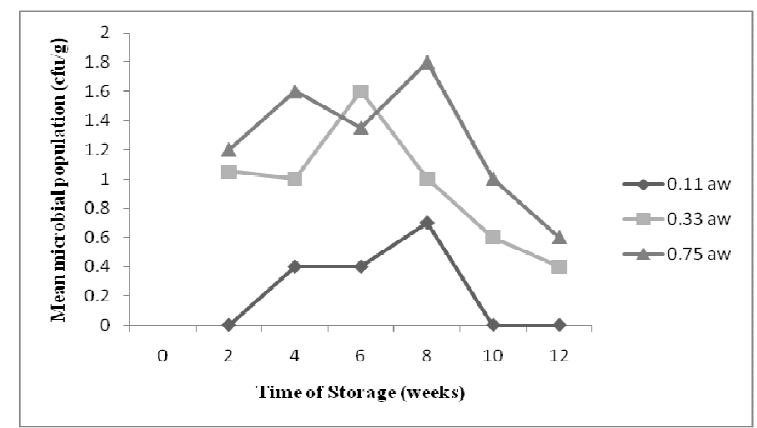

Fig 1: Comparison of Water Activities and Mean Microbial Population of Smoke-dried Beef (cfu/g)

The yield of the product showed that cured smokedried beef had the highest yield of $56.35 \%$ and the least of $32.1 \%$ was recorded in raw smoke-dried sample (Table 2). This agrees with reported cases which stressed that there is a lot of shrinkage in smoke-dried beef production which depends to some extent on the treatments applied (Obanu, 1988). The highest yield in cured smoke-dried beef is due to the curing ingredients applied which enhanced the waterholding properties in the meat than other treatments. The role of sodium tripolyphosphate as curing agent is of particular note as it increases the water-holding capacity of smoke-dried meat which eventually results in higher yield than the others (Ikeme, 1990). High yield is a positive indication of efficiency and profitability of the production process.

Results on table 3 show that shelf stability of smokedried beef was dependent on the type of treatment applied. The cured, smoke-dried products at twelve weeks of storage had the least microbial population of $0.43 \pm 0.03 \mathrm{cfu} / \mathrm{g}$ among the five treatments applied. The salted, cooked smoke-dried beef followed with a mean microbial population of $1.57 \pm$
$0.02 \mathrm{cfu} / \mathrm{g}$. The least shelf-stable smoke-dried beef in terms of treatments applied was the raw smoke-dried beef with a mean microbial population of $4 \pm 0.02$ $\mathrm{cfu} / \mathrm{g}$. Although smoke to which all treatment samples were subjected is bacteriostatic and bacteriocidal in function, the effects of sodium benzoate was pronounced (Igene and Tukura, 1986). They have observed in their study that smoke plays an integral role in preservation and will be more effective if combined with other preservatives like sodium benzoate (which is anti mycotic). The effect of the cure mixture is such that the moisture within the mixture is held bound by the salt and sugar molecules and this creates an unfavorable condition for microbial growth. Garbutt (1997) stated that salt creates an nfavorable environment for microbial growth by removal of moisture . The survival/growth of few microorganisms (fungi) observed in this product was because of the survival characteristics of mould and some halophytic (salt-loving) organisms. These organisms can thrive in the presence of salt, hence their survival in these products was not completely eliminated as observed by Okonkwo et al.(1994) and Garbutt (1997). 
The Effect of Preservative Methods.....

The water activity at which best shelf stability was observed and obtained was $0.11,0.33$ and 0.75 in descending order of stability (tables 4,5 and 6). The little microbial activities recorded at $\mathrm{a}_{\mathrm{w}}$ of 0.11 may be due to the distinct survival characteristics of fungi as reported by Garbutt (1997). This is because 0.11 is too extreme to support microbial growth. Although it is generally believed that fungi survives at $a_{w}$ of at least 0.61 , the survival of mould/fungi at $a_{w}$ of 0.11 (table 4) has also been reported (Eboigbe, 1999; Robert et al, 1995). However in table 6, the microbial population at $0.75 \mathrm{a}_{\mathrm{w}}$ is expected since most fungi can grow at $\mathrm{a}_{\mathrm{w}}$ of 0.61 and above. This suggests that the water activity of smoked beef should always be 0.11 or 0.33. Fusarium spp and Aspergillus flavipes were isolated from all treatment samples equilibrated at water activity of 0.33 except cured smoke-dried beef. The only organism present in the samples at $\mathrm{a}_{\mathrm{w}}$ of 0.11 was Aspergillus niger while Aspergillus flavus and Aspergillus aureous were isolated from the treatment samples equilibrated to water activity of 0.75 and those that were not equilibrated to any water activity. Although Aspergillus spp has been implicated as a potential toxin-producing organism to humans and animals, some species are also useful in the fermentation of oriental food products and industrial application in the production of organic acids or enzymes (Robert et al, 1995). It is therefore advised that water activity equilibration in dried food storage (especially smoke-dried beef) be encouraged and practiced. This will ensure a more stable, wholesome and palatable food supply for consumrs.

In figure I, the microbial population of the sample with $0.11 \mathrm{a}_{\mathrm{w}}$ rose at the beginning then became stable and rose again at the eighth week and finally dropped (and remained at) zero. The microbial population of sample with $0.33 \mathrm{a}_{\mathrm{w}}$ was stable for the first four weeks, rose sharply at week six and then dropped slowly afterwards. The microbial population of treatment sample at $0.75 \mathrm{a}_{\mathrm{w}}$ rose at the beginning and dropped. It then rose from week six to eight and finally dropped slowly. The general trend of the microbial population is that it dropped over time in storage. It has been reported that dried foods are capable of increasing in their shelf life if the environment is dry and remained constant and this result in the loss of moisture into the atmosphere. The constant immediate environment of such packaged and stored food prevents hysteresis, thereby prolonging the shelf-life of such product (Ukhun, 1986). The products then become an unfavorable media for the attack, growth and multiplication of spoilage mocrorganisms.

Conclusion: This study has shown the importance of lowering the water activities (content) of stored products to various water activities (content) as well as the need to cure meat prior to smoking. It has also shown that the cured smoke-dried meat which was equilibrated to $0.11 \mathrm{a}_{\mathrm{w}}$ was the most shelf-stable. These combined effects of curing and low moisture content ensured preservation and extended shelf life.

\section{REFERENCES}

Asagbra, A.Y., Odunfa, S.A., Amao-Awua, W.K. and Jacobsen, M (1998). HACCP System for Traditional African Fermented Foods. Soy-Ogi World Association of Industrial and Technological Research Organisation (WAITRO), Danish Tech. Inst., Demnark.

Daniels, R.W. (1998). Home Food Safety. Food Technology Journal 52(2): 54-56

Eboigbe, L. (1999). Incidence of Aspergillus spp in Various Forms of Groundnut (Arachis hypogaea) and Control Measures. Undergraduate Project, University of Benin.

Frazier, W.C. (1967). Food Microbiology. McGraw Hill, pp 140-141

Garbutt, J. (1997). Essentials of Food Microbiology. ARNOLD: A member of the Hodder Headline Group, Loudo.

Igene, J.O. and Tukura, D.H. (1986). Effect of Processing Methods on Product Characteristics, Lipid, Fatty Acid Composition and Oxidative Stability of Smoke-dried Beef. J.Sci., Food Agric $37: 818$

Ikeme, A.I. (1990). Meat Science and Technology. African Rep. Publishers Limited

Jacob, M.(1989). Safe Food Handling- A Training Guide ofr Management of food Service establishments. World Health Organisation.

Jideani, V.A., Nkama, I., Agbo, E.B. and Jideani, I.A. (2000). Hazard Analysis and Critical Control Points (HACCP) Evaluation of Traditional Fura Production. Proceedings of $24^{\text {th }}$ Annual NIFST Conference, 20-24 ${ }^{\text {th }}$ Nov., 2000. 
The Effect of Preservative Methods.....

Newsome, R. (1994). Of Food safety; Pineapple and HACCP. J. Food Tech. 6:7.

Obanu, Z.A. (1988). Preservation of Meat in Africa by Control of the Internal Aquaeous Environment in Relation to Food Quality and Stability. In: Food Preservation By Moisture Control. Elsevier Applied Science.

Okonkwo, T.M., Obanu, Z.A. and Onwuka, N.D. (1994). Quality Characteristics, Amino Acid and Fatty Acid Profile of Some Nigerian Traditional Hotsmoked Meat Products. Nigerian Food Journal 12:46-54

Pearson, A.M. and Tauber, F.W. (1984). Processed Meats, $2^{\text {nd }}$ Ed Av. Pub. Inc pp 69-85.

Robert, A.S., Hockstra, E.S., Frisvad, J.C and Filterborg, O. (1995). Introduction to FoodBorne Fungi. Central Bureau Voor Schiemmelcultures, the Netherlands.
Rockland, L.B.and Nishi, S.K. (1980). Influence of Water Activity on Food Product Quality and Stability. J. Food Tech. 34:334-335.

Ukhun, M.E. (1991). Control of water Activity. The Keys to Production of Stable, Safe and Nutritious Food in Nigeria. Policy Analysis Department, Federal Ministry of Industries UNDP/UNIDO/TAP, pp 173-176.

Ukhun, M.E. (1986). Effect of Storage and Processing on the Nutritional Value of certain Nigerian Foods. Experienta 42:948-950.

Ukhun, M.E. and Dibie, E.N. (1989). Cyanide Content of Cassava Mash and Gari Flour and Influence of Water Activity $\left(\mathrm{a}_{\mathrm{w}}\right)$ during Storage. Bulletin of Environmental Contamination and Toxicology 42(4):548-552. 